\title{
Assistance Decision Model for SMEs
}

\author{
Inayatulloh, Bachtiar Saleh Abbas , Agung Trisetyarso , Wayan Suparta, Chul-Ho Kang
}

\begin{abstract}
SMEs in Indonesia are one of the economic drivers of the nation. Its presence and development shows a sizeable contribution to Gross Domestic Income (GDP) each year. With this background, the Indonesian government provides stimulants in the form of financial assistance for the special SMEs for beginner SMEs. The government is encouraging the growth of SMEs by providing assistance to SMEs. During this time the process of determining the provision of assistance is done manually so that it is less effective and efficient. Therefore, the purpose of this study is to make a decision support model for the Ministry of SMEs to provide financial assistance to SMEs. The research method uses AHP and Promethee. Based on the results and discussion produced a Decision Support System model to help the Ministry of SMEs provide financial assistance to SMEs. The conclusion of this study is the suitability of SME ministry staff with the resulting model in the form of ease in the decision making process of providing assistance to SMEs.
\end{abstract}

Keywords: SMEs, DSS, AHP.

\section{INTRODUCTION}

The Government of Indonesia supports Small and Medium Enterprises through financial assistance and other assistance to help SMEs develop their businesses [1]. Currently, the assessment process for SMEs who deserve assistance uses a manual process that results in less effective decisions. The evaluation of the UMKM has been carried out through a manual process by considering several aspects. The assessment stage by considering several aspects without using standard methods as a basis but based on subjectivity individuals who result in inconsistent assessment resultsTherefore, this research aims to create a model using decision support systems and analytical hierarchical processing that can be used to help provide assessments for SMEs who will receive financial assistance from the

Manuscript published on January 30, 2020.

* Correspondence Author

Inayatulloh*, Computer Science Department, Binus Graduate Program-Doctor of Computer Science, Bina Nusantara University, 11480 West Jakarta,

Bachtiar Saleh Abbas, Computer Science Department, Binus Graduate Program - Doctor of Computer Science, Bina Nusantara University, and 11480 West Jakarta, Indonesia.

Agung Trisetyarso, Computer Science Department, Binus Graduate Program - Doctor of Computer Science, Bina Nusantara University, 11480 West Jakarta, Indonesia.

Wayan Suparta, Department of informatics, Universitas Pembangunan Jaya, South Tangerang, 15413, Banten, I donesia.

Chul-Ho Kang, Computer Science Department, Binus Graduate Program-Doctor of Computer Science, Bina Nusantara University, 11480 West Jakarta, Indonesia.

(c) The Authors. Published by Blue Eyes Intelligence Engineering and Sciences Publication (BEIESP). This is an open access article under the CC-BY-NC-ND license

(http://creativecommons.org/licenses/by-nc-nd/4.0/) government.. AHP and DSS are a system that helps in making the right decision by using several mechanisms that will result in better decisions. SMEs is a small-scale business entity using the constraints of company assets.

DSS is a method used to solve a problem by using several criteria that will be taken into consideration in producing a decision [5]. Related to AHP and DSS, several studies have been conducted using the same method, namely the selection of Leader Culling [6], then Promethee and AHP are also used in mining activities [7], other research using the same method is determining the best supplier [8]

The purpose of this research is to make a decision making model for funding assistance for SMEs in Indonesia using the Promethee and AHP methods. Of the several methods available then the Promethee and AHP are suitable for SMEs DSS because this method solves the problem into a number of parts that simpler organize parts or components into hierarchical arrangements.

The Indonesia government made a policy to help SMEs to develop their businesses by providing financial assistance and training. Government policies to provide assistance to SMEs are outlined in government regulations governing business scales included in SMEs. Criteria for small businesses according to Law no. 9 of 1995 the Republic of Indonesia is as follows:[1]

Has a net worth of at most Rp. 200,000,000.- (Two Hundred Million Rupiah) excluding land and buildings for business premises, are annual sales results of at most Rp. 1,000,000,000, - (One Billion Rupiah), Owned by Indonesian Citizens, Standalone, not a subsidiary or branch company that is not owned, controlled, or affiliated directly or indirectly with Medium Enterprises or Large Enterprises, in the form of individual businesses, business entities that are not legal entities, or business entities that are legal entities, including cooperatives

\section{LITERATURE STUDY}

\section{A. Analytical Hierarchical Processing (AHP)}

1) AHP was first introduced by Dr. Thomas L. Saaty from Wharton around the 1970s by making some decision criteria and some of the most determined alternatives [9].AHP is a way to solve problems with a high level of complexity and occur in an unstructured environment which is then changed into several components. the component settings are arranged with a hierarchical arrangement. one variable will be compared subjectively to another variable. each variable will be compared with other variables and given weight according to high priority and low priority which will affect the outcome of decision making.AHP brings together several assessments such as personal judgments that are subjective. 


\section{Assistance Decision Model for SMEs}

the next step is to determine the assessment criteria and alternative choices. criteria can be divided into several sub criteria and each subcritery has a different intensity.

2) Determine the priority of elements.

The first step is to arrange variables that have been determined before and then compared in pairs with other variables. Variables that are compared in pairs follow predetermined criteria which are compared using a matrix. The resulting matrix will be the result of work to see consistency, gather more information. This matrix can also be used to create from predetermined variables. The matrix can also be used to make a sensitivity analysis of all variables which are then used to make changes to the assessment of the variables used..

The matrices are used to compare all criteria with pairs performed at the highest level. This stage is carried out for the selection of criteria, for example $\mathrm{C}$, then from the level below the element to be taken, for example A1, A2, A3, A4, A5, arranged in a matrix.

The second process is assigning numbers or scales to each criterion compared to other criteria in pairs using priority levels. This number or scale is worth one to nine which represents the lowest level for scale one and scale nine for the highest level if there are criteria that meet the same criteria in the comparison matrix then the scale is worth one. If the comparison of a criteria gets a certain value then the other criteria are the opposite value. Table 1 explains the scale of criteria from one to nine based on the importance of the criteria

Table 1 - Scale of relative importance (according to Saaty $(1977 ; 1980)$ ).

\begin{tabular}{|c|c|}
\hline $\begin{array}{c}\text { Intensity } \\
\text { of importance }\end{array}$ & Definition \\
\hline $\mathbf{1}$ & Equal importance \\
\hline 2 & Weak \\
\hline $\mathbf{3}$ & Moderate importance \\
\hline 4 & Moderate plus \\
\hline $\mathbf{5}$ & Strong importance \\
\hline 6 & Strong plus \\
\hline $\mathbf{7}$ & Very strong or \\
\hline 8 & Very, very strong \\
\hline $\mathbf{9}$ & Extreme importance \\
\hline
\end{tabular}

$F$ (.) Is a criterion of a function then $P(\ldots)$ is a function preference. Therefore, function preferences can be flexibly determined [10]. The preference function $\mathrm{Pj}(\mathrm{x}, \mathrm{y})$ means an alternative to the preference, which means the alternative given to $\mathrm{x}$ and $\mathrm{y}$.

\section{B. Promethee}

Promethee was first announced by Professor Jean Pierre Brands (Universiteit Brussels) in 1982. Promethee is a method used to compare rankings of several alternatives [10].

\section{Decision Support System (DSS)}

Decision Support System (DSS) is a method commonly used to make decisions. SPK does not directly produce an alternative decision but uses another stage that will produce data analysis with the existing model (Kusrini, 2007).

\section{METHODOLOGY OF RESEARCH}

Ministry of SMEs Republic of Indonesia determines several main criteria that must be fulfilled by the institution, namely legality, general requirements, special requirements. Therefore, the Legality criteria have three sub-criteria, the general requirements have five sub-criteria and special requirements have two sub-criteria. Determination of criteria and aspects used based on government regulations through the law. The feasibility of the results of the assessment is based on several criteria in the table below

\begin{tabular}{|l|l|l|l|}
\hline No & Aspect & \multicolumn{2}{|l|}{ Score } \\
\hline & & 5 & 1 \\
\hline A1 & $\begin{array}{l}\text { SMEs Have a } \\
\text { formal } \\
\text { organization }\end{array}$ & Yes & No \\
\hline A2 & $\begin{array}{l}\text { SMEs just started } \\
\text { a business for at } \\
\text { least 6 months }\end{array}$ & Yes & No \\
\hline A3 & $\begin{array}{l}\text { SMEs engaged in } \\
\text { production }\end{array}$ & Yes & No \\
\hline
\end{tabular}

\begin{tabular}{|c|c|c|c|}
\hline \multicolumn{4}{|c|}{ General requirements } \\
\hline & & 5 & 1 \\
\hline B1 & $\begin{array}{l}\text { Recipient } \\
\text { Candidates submit } \\
\text { detailed proposals } \\
\text { including } \\
\text { technical data in } \\
\text { accordance with } \\
\text { Technical } \\
\text { Guidelines; }\end{array}$ & Yes & No \\
\hline B2 & $\begin{array}{l}\text { Have a legality } \\
\text { document for the } \\
\text { recipient; }\end{array}$ & Yes & No \\
\hline B3 & $\begin{array}{l}\text { In the current year } \\
\text { the budget is not } \\
\text { being or will } \\
\text { receive similar } \\
\text { facilitation from } \\
\text { APBD funds } \\
\text { (Regional } \\
\text { Revenue and } \\
\text { Expenditure } \\
\text { Budget) and / or } \\
\text { APBN (Budget) } \\
\text { State Revenues } \\
\text { and Expenditures) } \\
\text { from other } \\
\text { Ministries / } \\
\text { Institutions; }\end{array}$ & Yes & No \\
\hline B4 & $\begin{array}{l}\text { The highest age is } \\
45 \text { years }\end{array}$ & Yes & No \\
\hline B5 & $\begin{array}{l}\text { The lowest } \\
\text { education is junior } \\
\text { high school. }\end{array}$ & Yes & No \\
\hline
\end{tabular}


Table 2. The criteria for feasibility assessment

\begin{tabular}{|l|l|l|l|}
\multicolumn{1}{|l|}{ A. Special requirements } & \multicolumn{1}{|l|}{} \\
\hline C1 & $\begin{array}{l}\text { SMEs have a small } \\
\text { and medium } \\
\text { business license or } \\
\text { the UMKM } \\
\text { Register } \\
\text { Certificate from } \\
\text { the Indonesian } \\
\text { Ministry of } \\
\text { Cooperatives and } \\
\text { SMEs }\end{array}$ & No \\
\hline C2 & $\begin{array}{l}\text { The SMEs has a } \\
\text { business } \\
\text { development } \\
\text { proposal that at } \\
\text { least contains the } \\
\text { identity of the } \\
\text { proposer, business } \\
\text { information, profit } \\
\text { / loss calculation, } \\
\text { planned use of } \\
\text { funds and } \\
\text { photographs of } \\
\text { business activities }\end{array}$ & \\
\end{tabular}

Based on table 1 above, an assessment of the community who submitted a request for assistance for their business development from the employer had a multi-criteria variable. We make models to make decisions with several criteria. Therefore, this model can be used by the government to determine which institutions get assistance.If the proposal requirements are incomplete, the government will provide information to the community to complete the proposal the proposal requirements are incomplete, the government will provide information to the community to complete the proposalDSS that is built and developed uses data in table 1. Ownership data and estimated data will be stored in Management data. Therefore, the AHP and PROMETHEE are references that will be used to assess the feasibility of the partnership. Eligibility of incoming proposals will be given a ranking made material can be made for analysis of DSS. Each criterion has an initial weight. Table 3 shows the weights between criteria.

Table 3 Weight comparison matrix

\begin{tabular}{|l|l|l|l|}
\hline & Criteria 1 & $\ldots$ & Criteria n \\
\hline Criteria 1 & & & \\
\hline Criteria 2 & & & \\
\hline Criteria 3 & & & \\
\hline Criteria 4 & & & \\
\hline Criteria n & & & \\
\hline
\end{tabular}

\begin{tabular}{|l|l|l|l|l|}
\hline Alternative & $\mathrm{f1}()$. & $\mathrm{F} 2()$. & $\ldots$ & $\mathrm{fm}()$. \\
\hline a1 & $\mathrm{f} 1(\mathrm{a} 1)$ & & $\ldots$ & \\
\hline a2 & $\mathrm{f1}(\mathrm{a} 2)$ & & $\ldots$ & \\
\hline$\ldots$ & $\ldots$ & $\ldots$ & $\ldots$ & $\ldots$ \\
\hline an & & & $\ldots$ & $\mathrm{fm}(\mathrm{an})$ \\
\hline
\end{tabular}

AHP produces weights from criteria that will describe the consistency test. Evaluation of SMEs proposals will use a consistency test from the results of AHP calculations. Table III illustrates the data from the initial analysis. Alternatives represent SMEs, only FM (.) Represents judgment.

The proposal that has the highest value means to be the proposal with the best alternative.

\section{RESEARCH DIAGRAM}

Figure 1 shows the process of completing a proposal in accordance with predetermined requirements. This activity is carried out by examining all main documents and supporting documents as the first requirement to be able to pass to the next stage. After all documents have met the requirements, a complete proposal can be a candidate for recipient of assistance.

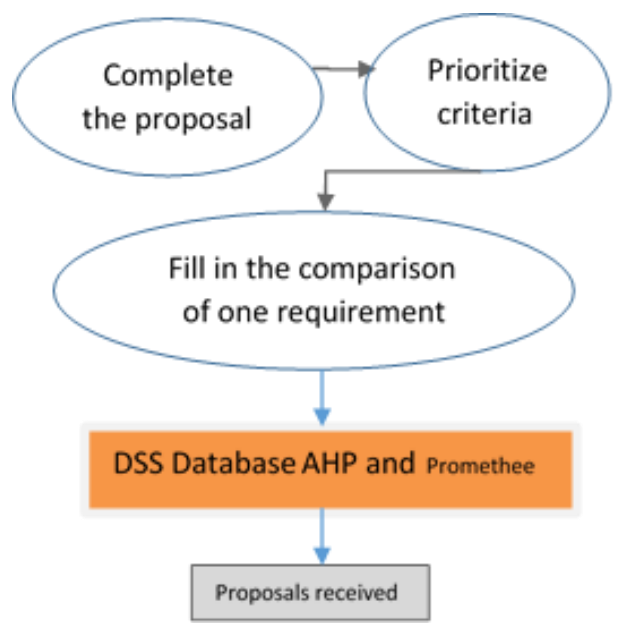

Figure 1.

Figure 2 explains the SME process that prepared the proposal. The complete proposal accompanied by supporting documents is submitted to the village government. The village government verifies and validates the SME proposal if the proposal is complete then the local government submits the SME proposal to the provincial government. If the proposal is not complete, the local government returns the proposal to the relevant SME. The provincial government has again verified and validated the SME proposal. If the results of verification and validation have been carried out, then the provincial government will make a cover letter about SMEs that have passed the verification and validation test addressed to the Ministry of SMEs of the Republic of Indonesia. 


\section{Assistance Decision Model for SMEs}

\begin{tabular}{|r|l|r|l|}
\hline No & Criteria & $\begin{array}{l}\text { Range } \\
\text { Score }\end{array}$ & Explain \\
\hline 1 & A1 & 5-Jan & Xxxxxx \\
\hline 2 & A2 & 5-Jan & Xxxxxx \\
\hline 3 & A3 & 5-Jan & Xxxxxx \\
\hline 4 & B1 & 5-Jan & Xxxxxx \\
\hline 5 & B2 & 5-Jan & Xxxxxx \\
\hline 6 & B3 & 5-Jan & Xxxxxx \\
\hline 7 & B4 & 5-Jan & Xxxxxx \\
\hline 8 & B5 & 5-Jan & Xxxxxx \\
\hline 9 & C1 & 5-Jan & Xxxxxx \\
\hline 10 & C2 & 5-Jan & Xxxxxx \\
\hline
\end{tabular}

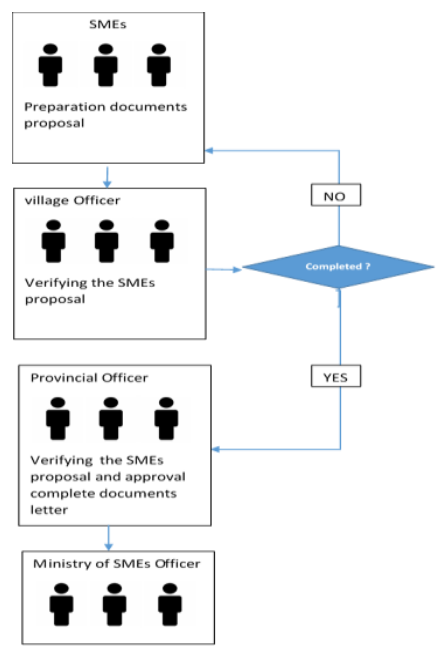

Figure 2

Table 4 explain the step to determine the comparison of one criterion with other criteria. Comparative values are subjective and logical based on the experience and knowledge of decision makers.

The results of the process of calculating AHP and Promethee which will produce a ranking proposal that has the highest value.

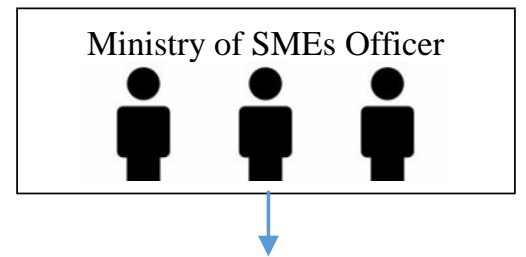

List of SMEs

Table 4. Comparison matrix and list SMEs

\begin{tabular}{|c|c|c|}
\hline No & SMEs & Explain \\
\hline 1 & SME 1 & Xxxxxx \\
\hline 2 & SME 2 & XXXXXX \\
\hline 3 & SME 3 & Xxxxxx \\
\hline 4 & SME 4 & $\mathrm{Xxxxxx}$ \\
\hline $\mathrm{N}$ & SME n... & XXXXXX \\
\hline
\end{tabular}

Figure 3, 4,5 and 6 explain The next step by user to prioritize the criteria. Decision makers determine the criteria and scores of each criterion. For example, if SMEs have business legality supporting documents, the score is given a

score of five and if SMEs does not have business legal documents, then the score 1 . The same is done for all aspects and general criteria and special criteria.

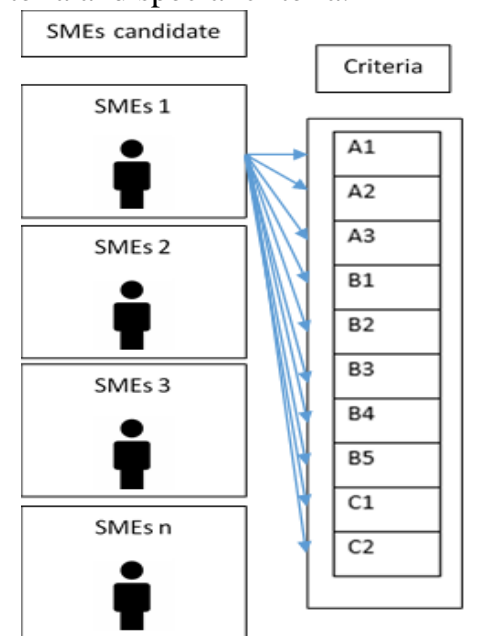

Figure 3

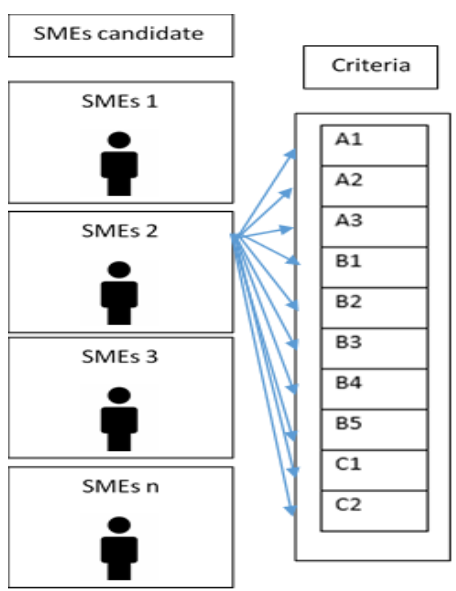

Figure 4.

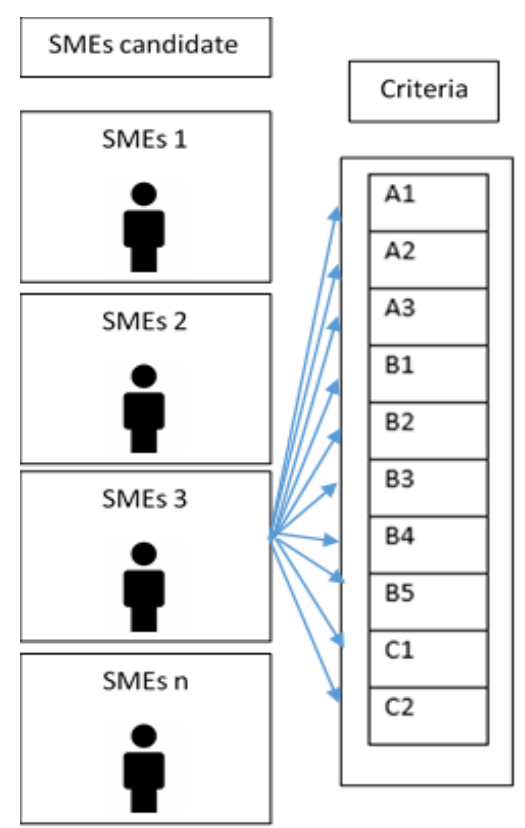

Figure 5. 


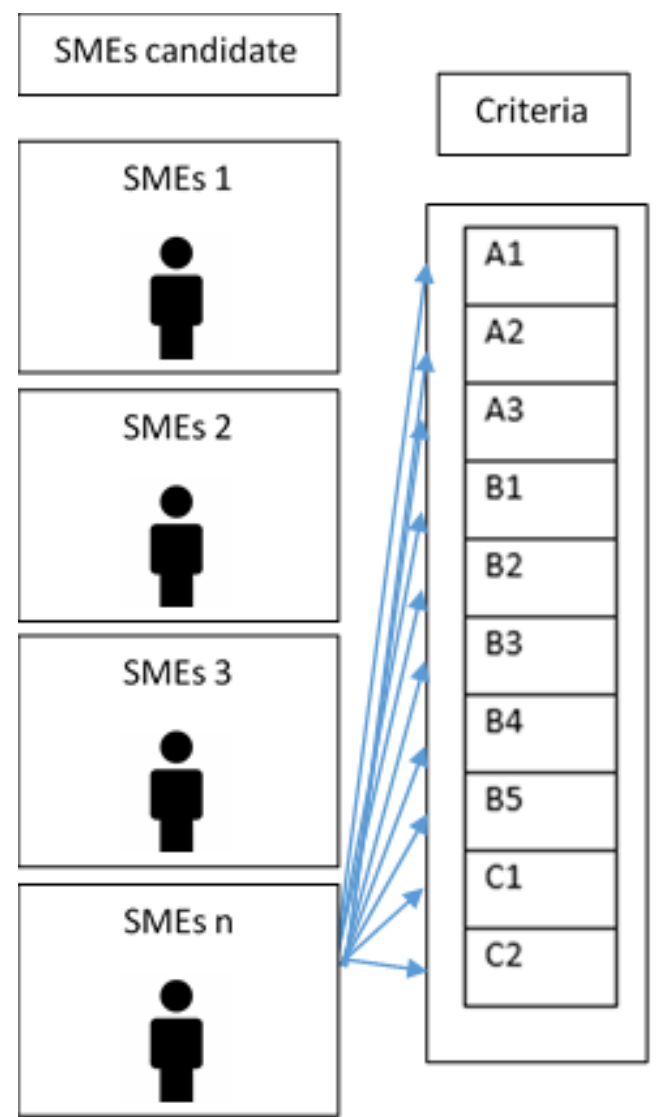

Figure 6

Comparing the criteria

The next step is to compare one criterion with another criterion and give a score on a criterion that is higher in value.

Figure 7 explain when A1 is 5 times more important than A2 then A1 has a score of 5

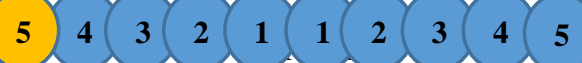

Figure 7 explain when A3 is 3 times more important than A1 then $\mathrm{A} 3$ has a score of 3

A1

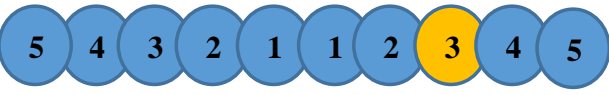

Figure 8

Figure 8 explain when A2 is 4 times more important than A2 then $\mathrm{A} 2$ has a score of 4

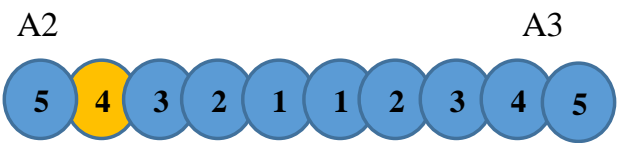

Figure 9

Figure 9 explain when B2 is 3 times more important than B1 then $\mathrm{B} 2$ has a score of 3

B1

B2

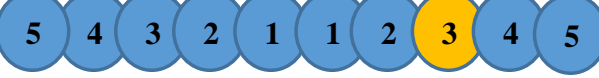

Figure 10
Figure 10 explain when B2 is 3 times more important than B3 then $\mathrm{B} 2$ has a score of 3

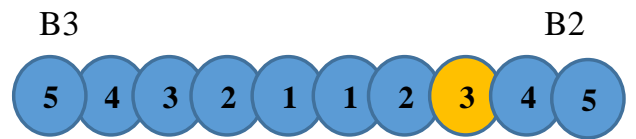

Figure 11

Figure 11 explain when B2 is 3 times more important than B4 then $\mathrm{B} 2$ has a score of 3

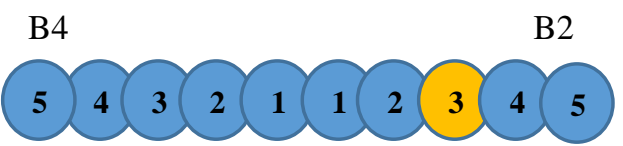

Figure 12

Figure 12 explain when B2 is 3 times more important than B5 then $\mathrm{B} 2$ has a score of 3

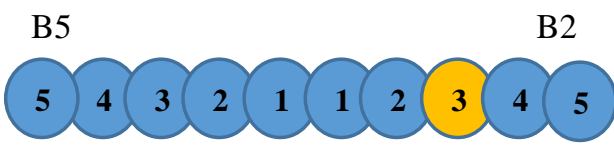

Figure 13

Figure 13 explain when B1 is 5 times more important than B2 then $\mathrm{B} 1$ has a score of 5

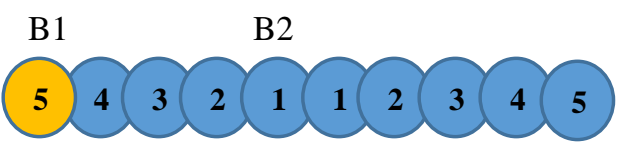

Figure 13

Figure 14 explain when B1 is 5 times more important than B3 then B1 has a score of 5

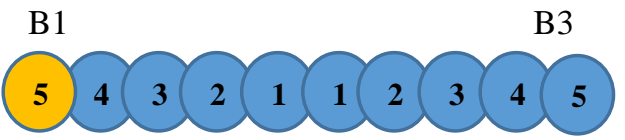

Figure 14

Figure 15 explain when B1 is 5 times more important than B4 then $\mathrm{B} 1$ has a score of 5

B1

B4

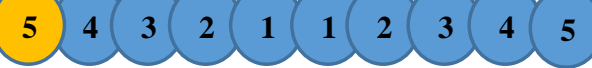

Figure 15

Figure 16 explain when B1 is 5 times more important than B5 then $\mathrm{B} 1$ has a score of 5
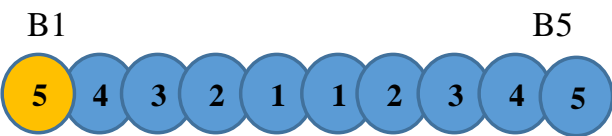

Figure 16

Figure 17 explain when B3 is 4 times more important than B1 then B3 has a score of 4

\section{Published By:}

Blue Eyes Intelligence Engineering DOI:10.35940/ijrte.D5875.018520

\& Sciences Publication 


\section{Assistance Decision Model for SMEs}

B3

B1

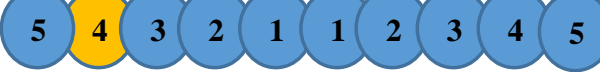

Figure 17

Figure 18 explain when B3 is 4 times more important than B2 then B3 has a score of 4

B3

B2

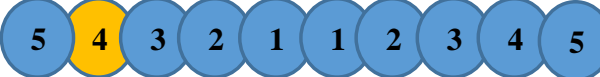

Figure 18

Figure 19 explain when B3 is 4 times more important than B4 then B3 has a score of 4

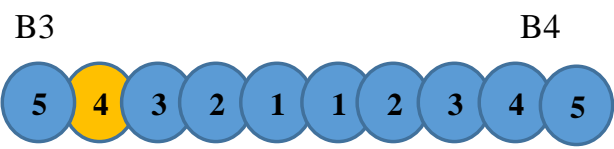

Figure 19

Figure 20 explain when B3 is 4 times more important than B5 then B3 has a score of 4

B3

B5

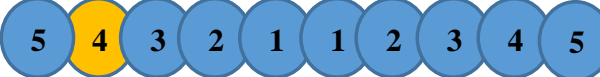

Figure 20

Figure 21 explain when B4 is 3 times more important than B5 then B4 has a score of 3

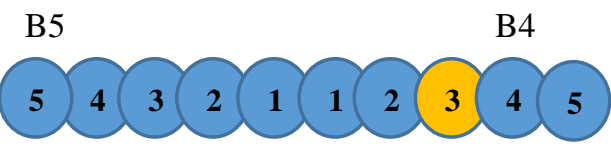

Figure 21

Comparison of criteria is also made for criteria A against B against $\mathrm{C}$ and vice versa.

\section{Comparing between SMEs base on the criteria}

Figure 22 explain when criterion $\mathbf{A} 1$ as the basis for evaluating comparison between ukm 1 and SME 1 and SME 2, 3 times better than SME 2 then SME 1 has a score of 3

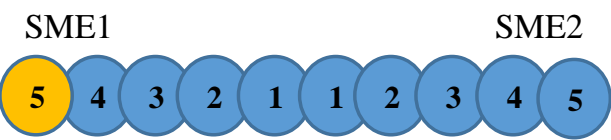

Figure 22

Figure 23 explain when criterion $\mathbf{A} 2$ as the basis for evaluating comparison between ukm1 and SME 1 and SME 2, 3 times better than SME 2 then SME 1 has a score of 3 .

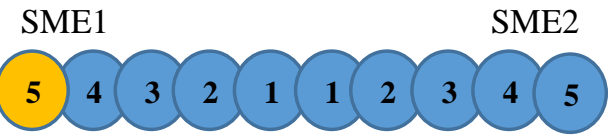

Figure 23

\section{RESULT AND DISCUSSION}

DSS model built for assistance for Indonesia's SMEs in the Figure 24.

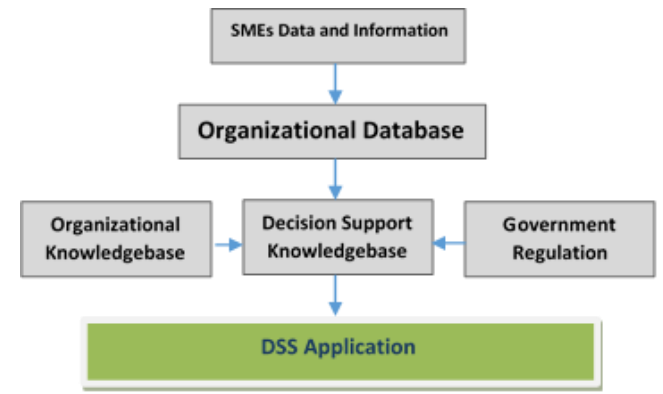

Figure 24

SMEs DSS model database which has 8 entities: Criteria, Sub Criteria, Assessment, assessement detail dan institution. Figure 25 explain Class Diagram of SMEs DSS model.

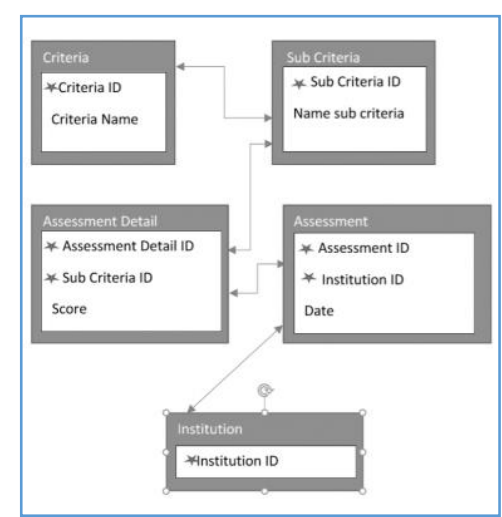

Figure 25

Evaluation Model

The model validation process was carried out using interview techniques and forum group discussion to the staff of the Ministry of SMEs. Some model validations use the following measurements:

1. Verification of input data is the activity of adjusting the data set that will be used in model validation. The use of data that is part of the DSS model that is built to adjust to the data format used by the user.

2. Verification of the process of determining the criteria is the activity of determining the criteria based on the Republic of Indonesia SMEs regulations.

3. Verification of alternative determination process is the activity of determining SMEs that have met the requirements based on proposals and other supporting documents.

4. Ease of use of the system is an assessment of the satisfaction of the activity of the use of the system by the user based on a series of processes in the SMEs DSS model.

5. Effectiveness and work efficiency is a measurement of work speed before and after using the SMEs DSS model.

6. Measurement of results is comparing the results of decisions using the SMEs DSS model and not using the SMEs DSS model.

Table 5 shows the evaluation stages of the DSS SMEs model that explains aspects that are evaluated, simulated and feedback from the user. 


\begin{tabular}{|c|c|c|}
\hline Evaluation & simulation & Feedback \\
\hline $\begin{array}{l}\text { Verification } \\
\text { input }\end{array}$ & $\begin{array}{l}\text { Users input } \\
\text { data to the } \\
\text { system }\end{array}$ & $\begin{array}{l}\text { The system must } \\
\text { be able to } \\
\text { accommodate } \\
\text { various types of } \\
\text { data from various } \\
\text { sources. Data } \\
\text { obtained from } \\
\text { SMEs submitted to } \\
\text { the local } \\
\text { government to the } \\
\text { provincial } \\
\text { government has a } \\
\text { different form, so } \\
\text { we need a system } \\
\text { that can accept all } \\
\text { types of data. }\end{array}$ \\
\hline $\begin{array}{l}\text { Verification } \\
\text { proses }\end{array}$ & $\begin{array}{ll}\text { Users } & \text { input } \\
\text { criteria } & \end{array}$ & $\begin{array}{l}\text { The criteria } \\
\text { used must be } \\
\text { flexible which can } \\
\text { be adjusted to } \\
\text { changes in } \\
\text { government } \\
\text { regulations. } \\
\text { Giving a score on } \\
\text { the criteria needs } \\
\text { to be added an } \\
\text { explanation that } \\
\text { will be used as a } \\
\text { reference to } \\
\text { determine the high } \\
\text { and low criteria } \\
\text { compared to other } \\
\text { criteria }\end{array}$ \\
\hline Ease of use & $\begin{array}{l}\text { The user } \\
\text { evaluates the } \\
\text { user interface } \\
\text { design }\end{array}$ & $\begin{array}{l}\text { The user } \\
\text { interface to be } \\
\text { designed and the } \\
\text { order of the } \\
\text { processes must be } \\
\text { adjusted to the } \\
\text { user's } \\
\text { convenience. } \\
\text { A system user } \\
\text { manual should be } \\
\text { added that will } \\
\text { help the user use } \\
\text { the system. }\end{array}$ \\
\hline $\begin{array}{l}\text { Effectiveness } \\
\text { and work } \\
\text { efficiency }\end{array}$ & $\begin{array}{l}\text { The user } \\
\text { evaluates } \\
\text { work } \\
\text { efficiency } \\
\text { using DSS }\end{array}$ & $\begin{array}{l}\text { Users need to } \\
\text { simulate the use of } \\
\text { the system with } \\
\text { real data. Where } \\
\text { the results of the } \\
\text { simulation can be } \\
\text { used as material } \\
\text { for comparison } \\
\text { with work without } \\
\text { using a system. }\end{array}$ \\
\hline $\begin{array}{l}\text { Measurement } \\
\text { of results }\end{array}$ & $\begin{array}{l}\text { The user } \\
\text { evaluates DSS } \\
\text { features }\end{array}$ & $\begin{array}{l}\text { The system needs } \\
\text { to be made with } \\
\text { complete features } \\
\text { so that the results } \\
\text { of decision making } \\
\text { can be compared } \\
\text { with the results of } \\
\text { decisions without }\end{array}$ \\
\hline
\end{tabular}

\section{ACKNOWLEDGMENT}

We gratefully acknowledge the supporting Bina Nusantara University Research Technology Transfer Office who funded this research until publication of this research.

\section{REFERENCES}

1. Undang undang no 9 Tahun 1995, Republic of Indonesia

2. S. Kumar, N. Parashar, A. HaleemAnalytical hierarchy process applied to vendor selection problem: small scale, medium scale and large scale industries ,Business Intelligence Journal, 2 (2) (2009), pp. 355-362

3. Lee, W. Kim, Y.M. Kim, K.J. OhUsing AHP to determine intangible priority factors for technology transfer adoption Expert Systems with Applications, 39 (7) (2012), pp. 6388-6395

4. K. Govindan, M. Kaliyan, D. Kannan, A.N. Haq Barriers analysis for green supply chain management implementation in Indian industries using analytic hierarchy process International Journal of Production Economics, 147 (1) (2014), pp. 555-568

5. G.C. Akkaya and C. Uzar, "The Usage Of Multiple-Criteria Decision Making Techniques On Profitability and Efficiency: An Application Of Promethee," International Journal Of Economics and Finances Studies,Vol. 5, No. 1, pp. 149-156, 2013.

6. Bagla V., Gupta A., and Sharma B., "Leader Culling using AHP-PROMRTHEE Methodology," Paper of International Conference Computer Intelligent, USA, 2012.

7. Bogdanovic D., Nikolic D., and Ilic I., "Mining Method Selection by Integrated AHP and PROMETHEE Method," Anais Acad Brasil Ciênc, 2012, 84, 219-233.

8. Safari H, Fagheyi M. S., Ahangari S. S., and Fathi M. R., "Applying PROMETHEE Method Based on Entropy Weight for Supplier Selection," Busin Management Strategies, 2012, 3, 97-106

9. Thomas L. Saaty, Decision making with the analytic hierarchy process, Katz Graduate School of Business, University of Pittsburgh, ,Int. J. Services Sciences, Vol. 1, No. 1, 2008.

10. Jean-Pierre Brans, Bertrand Mareschal,Multiple Criteria Decision Analysis: State of the Art Surveys pp 163-186, International Series in Operations Research \& Management Science book series (ISOR, volume 78)

\section{AUTHORS PROFILE}

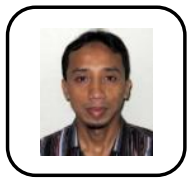

Inayatulloh Computer Science Department, Binus Graduate Program-Doctor of Computer Science, Bina Nusantara University, 11480 West Jakarta, Indonesia.inay@binus.ac.id.

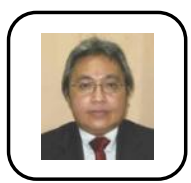

Bachtiar Saleh Abbas Computer Science Department, Binus Graduate Program-Doctor of Computer Science, major in industrial Engineering, Operation Research
Published By:

Blue Eyes Intelligence Engineering 
Assistance Decision Model for SMEs

Agung Trisetyarso Computer Science Department, Binus Graduate Program-Doctor of Computer Science, Bina Nusantara University, Studies Physics, Quantum Physics, and Group Theory.

Wayan Suparta Department of informatics, Universitas Pembangunan Jaya, South Tangerang, Major in Electronics Communication and Remote Sensing Applications

Chul Ho Kang Computer Science Department, Binus Graduate Program-Doctor of Computer Science, Bina Nusantara University, 11480 West Jakarta, Indonesia. chkang5136@kw.ac.kr 